\title{
Bir Üniversite Hastanesindeki Sağlık Çalışanlarının COVID-19 Riskli Temas Durumlarının Değerlendirilmesi
}

\section{Assessment of COVID-19 Risky Contact of Healthcare Workers in an University Hospital}

\author{
Gülçin YAPICl${ }^{1}$ (ID), Ahmet Öner KURT'1 (ID), Elif Tuğçe SOLMAZ1 (ID), \\ Aylin YENIOCAK TUNÇ (ID), Fatma BOZDAĞ ${ }^{1}\left(\right.$ ID), Bengü Nehir BUĞDAYCI YALÇIN ${ }^{1}(I D)$, \\ Ekin $\operatorname{KAPLAN}^{1}(I D)$, Burcu Ecem UĞUZ (ID), Eray DÜLGER ${ }^{1}(I D), \operatorname{Hülya~ÖZKAYALAR}^{2}($ ID), \\ Gönül $\operatorname{ASLAN}^{3}(I D)$, Gülden ERSÖZ4 (ID) \\ ${ }^{1}$ Mersin Üniversitesi Tıp Fakültesi, Halk Sağlığı Anabilim Dalı, Mersin. \\ ${ }^{1}$ Mersin University Faculty of Medicine Department of Public Health, Mersin, Turkey. \\ ${ }^{2}$ Mersin Üniversitesi Hastanesi, Enfeksiyon Kontrol Komitesi, Mersin. \\ ${ }^{2}$ Mersin University Hospital Infection Control Committee, Mersin, Turkey. \\ ${ }^{3}$ Mersin Üniversitesi Tıp Fakültesi, Tıbbi Mikrobiyoloji Anabilim Dalı, Mersin. \\ ${ }^{3}$ Mersin University Faculty of Medicine Department of Medical Microbiology, Mersin, Turkey. \\ ${ }^{4}$ Mersin Üniversitesi Tıp Fakültesi, Enfeksiyon Hastalıkları ve Klinik Mikrobiyoloji Anabilim Dalı, Mersin. \\ ${ }^{4}$ Mersin University Faculty of Medicine Department of Infectious Diseases and Clinical Microbiology, Mersin, Turkey.
}

\footnotetext{
* Bu çalışma, 4. Uluslararası 22. Ulusal Halk Sağlığı Çevrim içi Kongresi (13-19 Aralık 2020)'inde sözlü bildiri olarak sunulmuştur.
}

Makale Atıfı: Yapı ı G, Kurt AÖ, Solmaz ET, Yeniocak Tunç A, Bozdağ F, Buğdaycı Yalçın BN ve ark. Bir üniversite hastanesindeki sağlık çalışanlarının COVID-19 riskli temas durumlarının değerlendirilmesi. Mikrobiyol Bul 2021;55(2):161-179.

\section{ÖZ}

Sağlık çalışanları COVID-19 bulaşma riskinin en yüksek olduğu gruptur. Sağlık çalışanlarının hastalığa yakalanması kendi sağlıklarının yanında hastaneye başvuran hastalar, iş arkadaşları ve ev halkı için de risk oluşturmaktadır. Bu çalışmada bir üniversite hastanesindeki sağlık çalışanlarının COVID-19 ilişkili temas sonrası risk değerlendirmesi ve risk durumlarıyla ilişkili faktörlerin belirlenmesi amaçlanmışıı. Tanımlayıcı tipteki araştırmanın verileri 06.04-10.05.2020 tarihleri arasında COVID-19 riskli temasla başvuran 555 sağlık çalışanının 773 izlem kaydından elde edilmiştir. Sağlık çalışanlarından SARS-CoV-2 PCR pozitif olanlar "hasta", diğerleri "riskli temaslı" olarak değerlendirilmiş; risk değerlendirmesi Sağlık Bakanlığının "COVID-19 Teması Olan Sağılk Çalışanlarının Değerlendirilmesi Algoritması"na göre; risk yok, düşük, orta ve yüksek riskli temas olarak sınıflandırılmıştır. Katılımcıların risk düzeyleri ile demografik ve işyeri özellikleri, kişisel koruyucu kullanımları arasındaki ilişki değerlendirilmiştir. Verilerin değerlendirilmesinde ortalama, standart sapma, yüzde, analizlerinde ki-kare ve ANOVA testi kullanılımıştır. Sağlık çalışanlarının yaş ortalaması $34.4 \pm 7.6$ yıl olarak tespit edilmiştir. Temaslı olanların \%56.2'sinin kadın, \%62.9'unun evli ve \%17.5'inin ek hastalığı olduğu belirlenmiştir. Riskli temaslıların \%45.6'sının hemşire, \%18.4'ünün destek personeli ve \%16.9'unun hekim olduğu saptanmıştır. Temasların \%46.5'i orta riskli, \%28.0'i düşük riskli, \%17.1'i yüksek riskli ve \%8.4'ü riski olmayan temas şeklinde bulunmuştur. Riskli temasların \%38.2'si 
dahili/cerrahi kliniklerde çalışan sağlık personelinde gerçekleşmiştir. Sağlık çalışanlarının \%66.0'sı hasta bakım ve tedavisi sırasında, \%25'i iş arkadaşlarıyla sosyal ortamlardayken riskli temasta bulunmuşlardır. Çalışanlar arasındaki sosyal ilişkilerde yüksek riskli temasın daha fazla olduğu saptanmıştır. Sağlık çalışanlarının \%73.2'sinde temasa neden olan kaynak, iş arkadaşı olarak tespit edilmiştir. Yüksek riskli sağlık çalışanlarının yaş ortalaması, düşük riskli olanlara göre daha küçük bulunmuştur. Riskli temas sırasında sağlık çalışanlarının \%54.5'inin cerrahi maske taktığı, hastaların ise \%67.8'inde maske bulunmadığı tespit edilmiştir. İzlenen 555 sağlık çalışanından 37 (\%6.7)'sine COVID-19 tanısı konmuştur. Hastaların \%48.6'sının hemşire, \%18.9'unun hekim olduğu tespit edilmiştir. Sağlık çalışanlarının \%48.6'sının tanı sırasında COVID-19 servis, poliklinik veya yoğun bakımda çalışmakta olduğu tespit edilmiştir. Hastaların \%51.6'sında hastalık kaynağının iş arkadaşı olduğu düşünülmüştür. COVID-19 pozitifliğinin hemşireler ve hekimlerde daha sık olduğu görülmüştür. Riskli temasın COVID-19 hastalarının tedavi edildiği birimler dışındaki servislerde de gerçekleştiği ve en sık hastalara sağlık hizmeti verirken, ikinci sıklıkla çalışanlar arası sosyal ilişkiler sırasında gerçekleştiği belirlenmiştir. İşyerinde sağlık çalışanlarının birbiriyle korunmasız teması önemli bir risk kaynağı olarak tespit edilmiştir. Sağlık çalışanlarının kişisel koruyucu ekipman kullanımlarının yetersiz olmasının, orta ve yüksek riskli temasların fazla olmasına neden olduğu bulunmuştur. Sağlık hizmeti sunumu sırasında hasta ve yakınlarının maske kullanmaları, sağlık çalışanlarının ise kişisel koruyucu ekipmanlarını tam olarak kullanmaları riski azaltacaktır. Çalışanların dinlenme alanlarının fiziki olarak iyileştirilmesi ve molaların düzenlenmesi ile sosyal alanda iş arkadaşları arasındaki riskli temas azalacaktır.

Anahtar kelimeler: COVID-19; sağık çalışanı; risk değerlendirmesi.

\section{ABSTRACT}

Healthcare workers are the group with the highest risk of COVID-19 transmission. The illness of healthcare workers poses a risk to patients admitted to the hospital, colleagues and households besides their own health. In this study, it was aimed to determine the risk assessment and the factors associated with risk status of an university hospital healthcare workers after risky COVID-19 contact. The data of the descriptive study were obtained from 773 follow-up records of 555 healthcare workers who applied with COVID-19 risky contact between 06.04-10.05.2020. Employees who were positive for RT-PCR evaluated as "patients" and others as "risky contact". Risk assessment was classified as no risk, low, medium and high risk contact according to the "Algorithm of Assessment of Health Workers with COVID-19 Contact" of the Ministry of Health. The relationship between the risk levels of the participants and their demographic and workplace characteristics and their usage of personal protection were evaluated. Mean, standard deviation, percentage, chi-square and ANOVA tests were used in the analysis of the data. The average age of the healthcare workers was determined as $34.4 \pm 7.6$ years. It was determined that $56.2 \%$ of those who had contact were female, $62.9 \%$ were married and $17.5 \%$ had an additional disease. It was determined that $45.6 \%$ of the risky contacts were nurses, $18.4 \%$ were supportive personnel and $16.9 \%$ were doctors. While $46.5 \%$ of the contacts were found as medium, $28.0 \%$ low, $17.1 \%$ high risk and $8.4 \%$ risk free. $38.2 \%$ of risky contacts occurred while working in internal/surgical clinics. While $66.0 \%$ of the employees had risky contact during patient care and treatment, $25 \%$ had risky contact with colleagues in social settings. High-risk contact was higher in social relations between employees. The source of the contact was a colleague in $73.2 \%$ of the employees. The average age of high-risk employees was smaller than those of low-risk. While $54.5 \%$ of the employees wore surgical masks during contact, $67.8 \%$ of the patients did not have a mask. Of 555 employees followed, 37 (6.7\%) were diagnosed as COVID-19; $48.6 \%$ of the patients were nurses and $18.9 \%$ were doctors. It was determined that $48.6 \%$ of the healthcare workers were working in the COVID-19 service, outpatient clinic or intensive care unit at the time of diagnosis. The source of the infection was thought to be a colleague in $51.6 \%$ of the patients. COVID-19 was more common in nurses and doctors. It was determined that risky contact also occurred in services other than the units where COVID-19 patients were treated and risky contact often took place while providing healthcare to the patients and during social relations between the employees. Unprotected contact of the employees with each other in the workplace was identified as an important risk source. Inadequate use of personal protective equipment by healthcare workers led to an increase in medium and high risk contacts. The use of masks by patients and their relatives during the health service delivery and the proper use of personal protective equipment by healthcare professionals will reduce the risk. With the physical improvement of the rest areas of the employees and the arrangement of the breaks, the risky contact between colleagues in the social areas will be reduced.

Keywords: COVID-19; healthcare workers; risk assessment. 


\section{Giriş}

Çin'in Hubei eyaletinin Wuhan şehrinde 31 Aralık 2019'da sebebi bilinmeyen pnömoni olgularının Dünya Sağlık Örgütü’ne (DSÖ) bildirilmesinin ardından, 7 Ocak 2020'de etkenin daha önce insanlarda tespit edilmemiş yeni bir koronavirüs olduğu belirtilmiştir. Yeni etken 'SARS-CoV-2' olarak tanımlanmış, hastalık COVID-19 olarak isimlendirilmiştir'. DSÖ, COVID-19'u 30 Ocak 2020'de uluslararası boyutta halk sağlığı açısından acil durum, 11 Mart 2020'de ise pandemi olarak ilan etmiştir. Bu tarihte tüm dünyada 118319 olgu ve 4292 ölüm gerçekleşmiştir ${ }^{2,3}$. Türkiye'de ilk olgu Sağlık Bakanlığı tarafından 11 Mart'ta bildirilmiştir ${ }^{4}$. Hastalığın ilk tanımlandığı andan sonra yaklaşık on bir aylık zaman dilimi içinde 9 Kasım 2020 itibarılla dünya nüfusunun yaklaşık 50 milyonu virüs ile enfekte olmuş, 1 milyon 250 bini hastalığa bağlı ölmüştür ${ }^{5}$. Aynı tarih itibariyle Türkiye'de toplam 396831 olgu, 10972 ölüm gerçekleşmiştir ${ }^{6}$.

Virüsün temel kaynağı tam olarak bilinmemekle birlikte, zoonotik kökenli olduğu belirtilmiştir. İnsanlar arasında bulaşma şeklinin enfekte kişinin konuşma, öksürme/hapşırmasıyla ortama saçılan partiküllerin yakın temasta (1-1.5 m'den kısa mesafe) damlacık yoluyla sağlam kişiye bulaşması, bu partiküllerle kontamine olmuş yüzeylerden bulaşma veya hava yoluyla (aerosol) olduğu düşünülmektedir ${ }^{7-10}$. Etkenin ortalama inkübasyon süresi 5.2 gün, karantina süresi 14 gün olarak belirtilmiştir ${ }^{7-9}$. Bulaştııııılık, semptomlar ortaya çıkmadan 1-3 gün önce başlamakta, semptomların ortaya çıkmasıyla birlikte viral yük en yüksek seviyeye ulaşmakta ve zaman içerisinde azalmaktadır. Tanıda en geçerli yöntem olarak kullanılan SARS-CoV-2 polimeraz zincir reaksiyonu (PCR) pozitifliği asemptomatik kişilerde 1-2 hafta, hafif ve orta düzey hastalarda üç haftadan daha uzun, immünsüpresif ve ciddi olgularda çok daha uzun süre devam etmektedir. Asemptomatik olguların da bulaştıııcı olduğu belirtilmiştir $1^{0}$.

Toplumda yeni bir enfeksiyon olan COVID-19'a herkesin duyarlı olduğu bilinmekle birlikte sağlık çalışanları hastalık etkeninin bulaşma riskinin en yüksek olduğu gruptur ${ }^{9}$. Sağlık çalışanları pandemi döneminde herkesten daha fazla sayıda COVID-19 hastasıyla temas etmekte ve hastalar ile yakın temasta bulundukları çalışma ortamları nedeniyle hastalık etkenini kazanma riskleri artmaktadır. Bugüne kadar çeşitli ülkelerde yapılan çalışmalarda, sağlık çalışanlarında PCR pozitifliği \%2.09-14.0 arasında değişmektedir ${ }^{11-23}$. Sağlık çalışanlarında hastalığı geçirme sıklığı \%6.4-24.4 olarak belirlenmiştir ${ }^{12,16}$. DSÖ, sağlık çalışanları toplumların yaklaşık \%2-3'ünü oluşturmasına rağmen, COVID-19 olgularının \%14-35'inin sağlık çalışanı olduğunu bildirmektedir ${ }^{24}$. Türkiye'de bir üniversite hastanesinde sağlık çalışanlarının \%7.1'inin PCR pozitif olduğu belirlenmiştir ${ }^{25}$. Sağlık Bakanının 2 Eylül 2020'de yaptığı açıklamaya göre, Türkiye'de toplam olgu sayısı 273301 kişi olup bunların 29865 'i sağlık çalışanıdır ${ }^{26}$. Buna göre, Türkiye'de tüm hastaların \%11'ini sağlık çalışanları oluşturmaktadır. Çin, İtalya, Almanya gibi ülkeler sağlık çalışanı ölümlerinin önemli boyutlarda olduğunu belirtmiştir $9,16,20$. Uluslararası Af Örgütü, tüm dünyada yedi binin üzerinde sağlık çalışanının COVID-19 nedeniyle hayatını kaybettiğini ancak bu sayıların bildirilenlerden daha yüksek olabileceğini vurgulamaktadır ${ }^{27}$. Sağlık Bakanı yaptığı açıklamada, 2 Eylül'de Türkiye'de COVID-19 nedeniyle 52 sağlık çalışanının hayatını 
kaybettiğini bildirirken, 3 Eylül'de Türk Tabipleri Birliği başkanı bu sayının 72 olduğunu belirtmiştir $^{26,28}$.

Sağlık çalışanlarının hastalığa yakalanmaları, sadece kendi sağlıkları üzerinde olumsuz etki yaratmamakta; hastanede sağlık hizmeti verdikleri hastalar, birlikte çalıştıkları iş arkadaşları ve ev halkına hastalığı bulaştırma riskini de artırmaktadır. DSÖ, sağlık çaIışanlarının sağlığını güvence altına almadan hastaların güvenliğinin sağlanamayacağını belirtmiştir. Ayrıca, pandemi döneminde sağlık çalışanlarının sağlığını korumak sağlık sisteminin devamı için önemli bir konudur ${ }^{25}$.

Bu çalışmada, Mersin Üniversitesi Hastanesi sağlık çalışanlarının olası ve kesin COVID-19 hastaları ile temas sonrası risk düzeylerinin değerlendirilmesi, risk durumlarıyla ilişkili faktörlerin belirlenmesi ve risk düzeyine göre alınan önlemlerin değerlendirilmesi amaçlanmıştır.

\section{GEREÇ ve YÖNTEM}

Bu çalışma, T.C. Sağlık Bakanlığının (Tarih: 14.06.2020 ve Sayı: 2020-06-10T14_34_14) ve Mersin Üniversitesi Klinik Araştırmalar Etik Kurulunun onayı ile gerçekleştirildi (Tarih: 08.07.2020 ve Karar No: 2020/475).

Bu çalışma öncesinde, Mersin Üniversitesi Hastanesi Başhekimliğinden 09.07.2020 tarihli, 41993462-774.01.01 sayılı resmi izin alındı. Mersin Üniversitesi Hastanesi COVID-19 Pandemi Komisyonunun 06.04.2020 tarihli toplantısında alınan karar sonrasında hastanede "Sağlık Çalışanı COVID-19 İzlem Birimi" kurulmuştur. Bu birim, pandemi sürecinde sağlık çalışanlarının sağlığının korunması çalışmalarına destek vermeyi, riskli COVID-19 temaslısı ya da hasta olan çalışanların izlemlerinin yapılmasını ve gerekli önlemlerin alınmasını sağlamayı amaçlamıştır. Bu çalışmadaki araştırmacılar, bu birimde görev yapan sağlık çalışanlarıdır. Araştırmanın verileri bu birimin tutmuş olduğu kayıtların değerlendirilmesiyle elde edildi.

Tanımlayıc tipteki çalışmanın verileri 06 Nisan-10 Mayıs 2020 tarihleri arasında COVID-19 riskli temas nedeniyle başvuran 555 sağlık çalışanının, 773 riskli temas izlem kaydını içermektedir. Hastanede görev yapan 2762 sağlık çalışanının \%20.1'i riskli temas nedeniyle değerlendirildi.

Temaslıların risk değerlendirmesinde T.C. Sağlık Bakanlığının "COVID-19 Teması Olan Sağlık Çalışanlarının Değerlendirilmesi Algoritması" dikkate alındı ${ }^{29}$. Çalışmada değerlendirilen veriler; yaş, cinsiyet, medeni durum, meslek, çalıştığı bölüm, kronik hastalık varlığı, sigara içme durumu, son 14 gün içerisinde ülke dışı veya şehir dışı seyahat, eve misafir kabulü, iş dışı COVID-19 hastasıyla riskli temas, olası riskli temasta bulunduğu olgu, temasta bulunduğu olgunun özellikleri, temaslı kişide semptom varlığı, PCR yapılma durumu, evde yaşadığı kişilerde COVID-19 hastalık varlığı, çalışanın kaldığı evi değiştirme durumu ve yapılan risk değerlendirmesinin sonucunu içermektedir.

Araştırmada, belirlenen tarihler arasında COVID-19 riskli teması olan 555 sağlık çaış̧anının 773 izleminin değerlendirilmesi yapıldı. Kişilere ait sosyodemografik özellikler 
555 kişi için verildi. Bu kişilerin 37'si hasta olarak belirlenen sağlık çalışanlarına aittir ve bu kişilerin verileri ayrı olarak değerlendirildi. Toplam 773 izlemin 37'si hasta olan sağlık çalışanlarına ait olduğundan hastalara ilişkin veriler çıkartılarak risk değerlendirmesiyle ilgili verilerin analizi 736 riskli temas üzerinden yapıldı.

06 Nisan-10 Mayıs 2020 tarihleri arasında yapılan izlemler analiz yapılırken haftalara göre değerlendirildi: 1. hafta: 06-12 Nisan 2020, 2. hafta: 13-19 Nisan 2020, 3. hafta: 20-26 Nisan 2020, 4. hafta: 27 Nisan-03 Mayıs 2020, 5. hafta: 04-10 Mayıs 2020.

Sağlık çalışanları kronik hastalıkları açısından sorgulandı. Kronik hastalığı olanlar; COVID-19 açısından riskli kronik hastalığı olanlar (kardiyovasküler hastalık, kronik respiratuvar hastalık, diabetes mellitus, kanser, hipertansiyon, nefrotik sendrom, kronik hepatit B ve hepatit B) ve olmayanlar olarak iki ayrı grupta değerlendirildi.

Araştırmada çalışanların görev yerleri beş grupta değerlendirildi:

i) Yetişkinlere rutin sağlık hizmet sunumunda görev yapan dahili ve cerrahi klinikler

ii) Yetişkin acil servis

iii) COVID-19 hasta ve risklilerine yönelik sağlık hizmeti sunan birimler (poliklinik, servis, yoğun bakım)

iv) COVID-19 dışındaki hastalara hizmet sunan yoğun bakım birimleri (reanimasyon yoğun bakım, kardiyoloji yoğun bakım, kalp damar cerrahi yoğun bakım, genel cerrahi yoğun bakım)

v) Çocuklara sağlık hizmet sunumunda görev yapan dahili ve cerrahi klinikler (çocuk sağlığı ve hastalıkları kliniği, çocuk yoğun bakım, çocuk acil servisi, çocuk cerrahi kliniği)

Araştırmada sağlık çalışanları "hasta" ve "riskli teması" olarak temel iki gruba ayrıldı. PCR pozitif olan sağlık çalışanları COVID-19 hastası olarak değerlendirdi. Riskli temaslar, Sağlık Bakanlığı kriterlerine göre; risk yok, düşük, orta ve yüksek riskli temas olarak değerlendirildi. Araştırmada COVID-19 hastalarıyla olası temas halindeki sağlık çalışanları için risk sınıflandırmasının ayrıntıları ve her risk düzeyine göre uygulanan risk yönetim planı Tablo I'de yer almaktadır.

i) Yoğun temas: solunum yolu örneği alınması, entübasyon, solunum sekresyonlarının aspirasyonu, non-invaziv ventilasyon, yüksek akımlı oksijen tedavisi, kardiyopulmoner resüsitasyon, nebülizer kullanımı, bronkoskopi/endoskopi, videolaringoskopi, ağız-boğaz-burun muayenesi, oftalmolojik muayeneler, santral kateter takılma işleminin uygulanmasi ${ }^{29}$.

ii) Hastalara sağlık hizmet sunumu: fizik muayene, öykü, hasta bakımı ve yoğun temas kriterleri dışındaki tıbbi girişimler.

iii) Sağlık çalışanlarınını kendi aralarında hastane içinde yemek yemesi, çay-kahve içme gibi sosyal ilişkileri. 


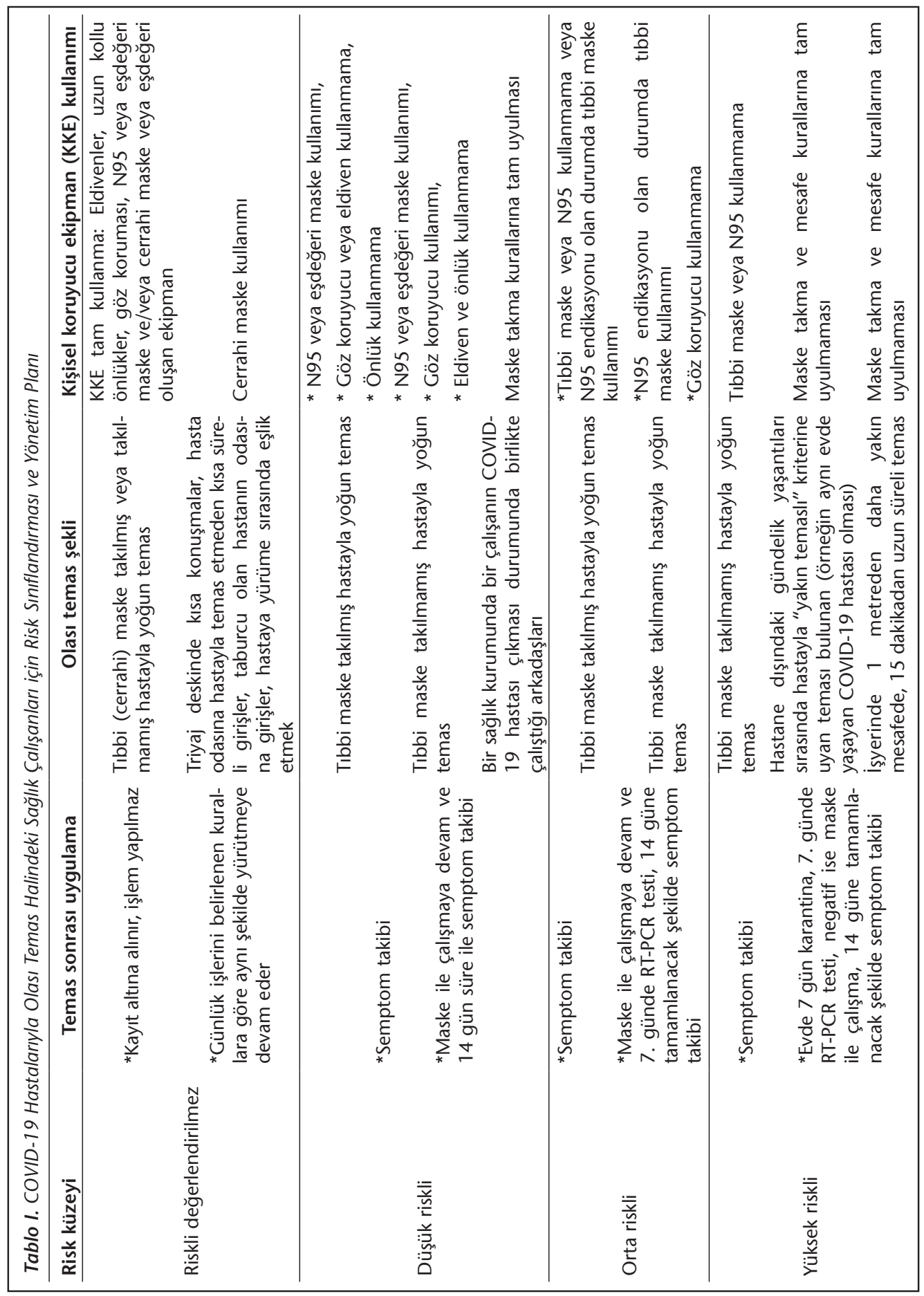


Verilerin analizinde katılımcıların risk düzeyleri ile demografik ve işyeri özellikleri arasındaki ilişkinin değerlendirilmesi temel alındı. Verilerin özetlenmesinde tanımlayıcı istatistikler (ortalama, standart sapma, minimum ve maksimum değer, yüzde), kategorik değişkenlerin karşılaştırılmasında ki-kare testi ve sayısal değişkenlerin karşılaştırılmasında ANOVA varyans analizi testi ve Post Hoc tst olarak Bonferroni testi kullanıldı. Çalışmada istatistiksel önemlilik düzeyi $\mathrm{p}<0.05$ olarak kabul edildi.

\section{BULGULAR}

Araştırma bulguları üç ana başlık altında sunulmuştur. Birinci olarak COVID-19 riskli temas nedeniyle izlemi yapılan 555 sağlık çalışanına ilişkin bulgular değerlendirilmiştir. ikinci olarak COVID-19 riskli temas nedeniyle "risk değerlendirmesi" yapılan 736 izlemin özelliklerine ve son olarak COVID-19 hasta tanısı konulan 37 sağlık çalışanının demografik ve çalışma yaşamı özelliklerine ilişkin bulgular paylaşılmıştır.

Sağlık çalışanlarının yaş ortalamasının 34.4 土 7.6 (20.4-59.6) yıl olduğu ve aynı evde yaşayan ortalama kişi sayısının $3.0 \pm 1.5$ (1-10) olduğu saptanmıştır. Tabloda yer alan bulgulara ek olarak; 312 kadın sağlık çalışanın 4 (\%1.3)'ünün riskli temas sürecinde gebe olduğu, ek hastalığı olduğunu belirten 97 kişiden 63 (\%64.9)'ünün hastalığının COVID-19 açısından riskli hastalık grubunda yer aldığı belirlenmiştir.

COVID-19 riskli temas nedeniyle izlemi yapılan 555 sağlık çalışanının demografik ve çalışma yaşamına ilişkin bulgular Tablo II'de yer almaktadır.

COVID-19 riskli temas nedeniyle "risk değerlendirmesi" yapılan 736 izlemin genel özellikleri bu başlık altında yer almaktadır.

Araştırmada 392 kişinin bir, 116 kişinin iki, 39 kişinin üç, 8 kişinin dört defa COVID-19 hastası ile riskli temasının olduğu saptanmıştır. Risk değerlendirmesi sonucunda riskli temasların \%46.5'inin orta riskli, \%28.0'inin düşük riskli, \%17.1'inin yüksek riskli olduğu ve \%8.4'ünde herhangi bir risk oluşmadığı belirlenmiştir. Risk değerlendirme sonuçlarının haftalara göre dağılımı değerlendirildiğinde üçüncü ve dördüncü haftalarda "yüksek riskli" temasların arttığı, toplam izlem sayısının dördüncü haftada en yüksek oranda olduğu gözlenmiştir. Temaslı izlem sayısının en az olduğu beşinci haftada risk oluşturmayan temasların diğer haftalara göre oldukça fazla olduğu gözlenmiştir (Tablo III, Şekil 1).

Riskli temas nedeniyle yapılan izlemlerin mesleklere göre durumu incelendiğinde; \%48.1'i hemşire, \%18.3'ü destek personeli ve \%14.9'u hekim olarak belirlenmiştir. Sekreterlerin \%23.5'inin ve hemşirelerin \%20.6'sının yüksek riskli teması olduğu belirlenmiştir. Temasların \%38.2'si dahili ve cerrahi servislerde çalışma sırasında, \%28'i ise COVID-19 hastalarının tanı ve tedavi işlemlerinin yapıldığı bölümlerde gerçekleşmiştir. Acil servis ve çocuk hastalıkları bölümlerinde çalışma durumlarında riskin daha düşük olduğu belirlenmiştir. Temasların \%66.0'sının hasta bakım ve tedavisi sırasında, \%25.0'inin kişiler arası sosyal ilişkiler sırasında olmuştur. Temasa neden olan kaynağın (\%73.2) sıklıkla iş arkadaşlarının olduğu belirlenmiştir. Kişiler arası sosyal ilişkiler sırasında "yüksek riskli te- 


\begin{tabular}{|c|c|c|}
\hline Değişkenler & Sayı & $\%$ \\
\hline \multicolumn{3}{|l|}{ Cinsiyet } \\
\hline Kadın & 312 & 56.2 \\
\hline Erkek & 243 & 43.8 \\
\hline \multicolumn{3}{|l|}{ Meslek } \\
\hline Hekim & 94 & 16.9 \\
\hline Hemşire & 253 & 45.6 \\
\hline Destek personeli & 102 & 18.4 \\
\hline Temizlik personeli & 54 & 9.7 \\
\hline Sekreter & 21 & 3.8 \\
\hline Sağlık teknikeri & 20 & 3.6 \\
\hline Teknik eleman (sağlık dışı) & 11 & 2.0 \\
\hline \multicolumn{3}{|l|}{ Görev yeri } \\
\hline Dahili ve cerrahi klinikler & 207 & 37.3 \\
\hline COVID servis, poliklinik ve yoğun bakım kliniği & 169 & 30.5 \\
\hline COVID dışı yoğun bakım klinikleri & 100 & 18.0 \\
\hline Çocuk sağlığı ve hastalıkları kliniği & 45 & 8.1 \\
\hline Acil servis & 34 & 6.1 \\
\hline \multicolumn{3}{|l|}{ Medeni durum } \\
\hline Evli & 349 & 62.9 \\
\hline Bekar & 206 & 37.1 \\
\hline \multicolumn{3}{|l|}{ Ek hastalık varlığı } \\
\hline Var & 97 & 17.5 \\
\hline Yok & 458 & 82.5 \\
\hline \multicolumn{3}{|l|}{ Sigara kullanımı } \\
\hline Evet & 219 & 39.5 \\
\hline Hayır & 336 & 60.5 \\
\hline \multicolumn{3}{|l|}{ Hastane tarafından COVID-19 korunma eğitimi verilme } \\
\hline Evet & 511 & 92.1 \\
\hline Hayır & 44 & 7.9 \\
\hline Toplam & 555 & 100.0 \\
\hline
\end{tabular}

mas" diğerlerine göre daha fazla tespit edilmiştir. Temastan sonra izlemlerin \%31.4'ünde semptom gelişmiş ve yapılan izlemlerin \%74.3'üne PCR testi yapılmıştır (Tablo IV). Yüksek riskli sağlık çalışanlarının yaş ortalaması düşük riskli olanlara göre daha küçük olarak belirlenmiştir (sırasıyla $32.5 \pm 6.9,35.3 \pm 7.5, F=4.059, \mathrm{p}=0.007$ ).

Riskli temas sırasında hastaların \%67.8'inde maske bulunmadığı saptanmıştır. Sağlık çalışanlarının riskli temas sırasında kişisel koruyucu ekipman (KKE) kullanımları değerlendirildiğinde; \%54.5'inin cerrahi maske, \%9.5'inin N95 ya da benzeri etkide maske, \%28.3'ünün eldiven, \%18.6'sının önlük, \%3.3'ünün yüz koruyucu, \%1.6'sının koruyucu 


\begin{tabular}{|c|c|c|c|c|c|c|c|c|c|c|}
\hline \multirow[b]{2}{*}{ 1. hafta: 06-12 Nisan 2020} & \multicolumn{2}{|c|}{ Risk yok } & \multicolumn{2}{|c|}{ Düşük risk } & \multicolumn{2}{|c|}{ Orta risk } & \multicolumn{2}{|c|}{ Yüksek risk } & \multicolumn{2}{|c|}{ Toplam* } \\
\hline & 19 & 12.6 & 44 & 29.1 & 80 & 53.0 & 8 & 5.3 & 151 & 20.5 \\
\hline 2. hafta: $13-19$ Nisan 2020 & 5 & 4.3 & 44 & 37.6 & 62 & 53.0 & 6 & 5.1 & 117 & 15.9 \\
\hline 3. hafta: $20-26$ Nisan 2020 & 10 & 5.1 & 47 & 23.9 & 86 & 43.7 & 54 & 27.4 & 197 & 26.7 \\
\hline 4. hafta: 27 Nisan-03 Mayıs 2020 & 19 & 8.1 & 59 & 25.0 & 105 & 44.5 & 53 & 22.5 & 236 & 32.1 \\
\hline 5. hafta: $04-10$ Mayıs 2020 & 9 & 25.7 & 12 & 34.3 & 9 & 25.7 & 5 & 14.3 & 35 & 4.8 \\
\hline Toplam & 62 & 8.4 & 206 & 28.0 & 342 & 46.5 & 126 & 17.1 & 736 & 100.0 \\
\hline
\end{tabular}

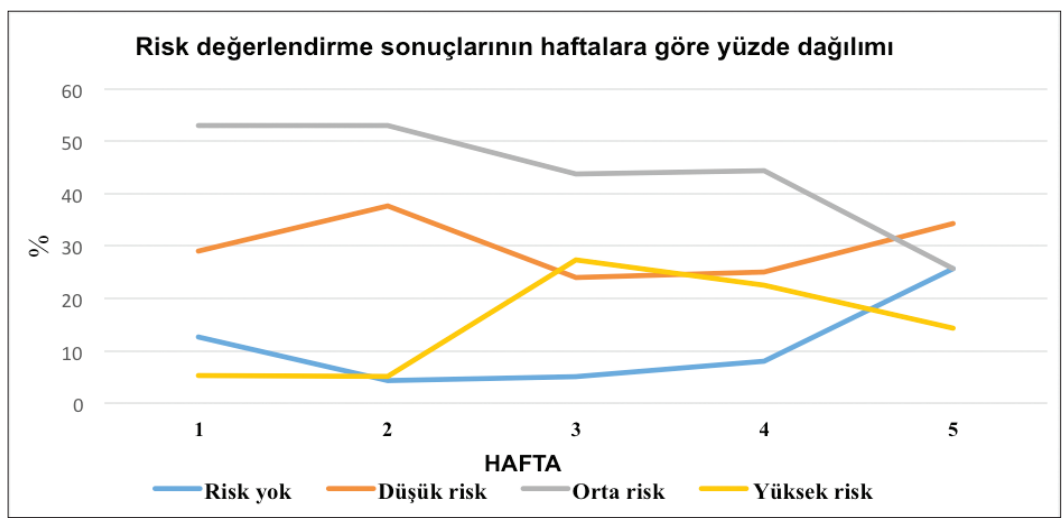

Şekil 1. Risk değerlendirme sonuçlarının haftalara göre dağılımı.

gözlük, \%0.5'inin tulum giydiği belirlenmiştir. Kişisel koruyucuları yeterli düzeyde uygulamadıkları için orta ve yüksek riskli temaslar gerçekleşmiştir (Tablo V).

Araştırma sürecinde izlemi yapılan 736 riskli temasın olası temas kaynağının, hastaneye tedavi amacıyla kabul edilen hastalar $(n=16)$, COVID-19 pozitif sağlık çalışanı $(n=32)$ ve işyeri dışında temas edilenler $(n=3)$ olduğu belirlenmiştir. Her kaynak için ortalama 14.3 kez izlem yapıldığı belirlenmiştir.

COVID-19 tanısı konularak takip edilen 37 kişinin demografik ve hastalığa ilişkin özellikleri bu başık altında değerlendirilmiştir.

İzlenen 555 sağlık çalışanından 37 (\%6.7)'sine COVID-19 hasta tanısı konmuştur. Hastaların yaş ortalaması $35.4 \pm 7.9$ ve evde yaşayan kişi ortalaması $3.6 \pm 1.3$ olarak belirlenmiştir. Hasta olan sağlık çalışanlarının \%48.6'sının hemşire olduğu ve \%48.6'sının tanı sırasında COVID servis, poliklinik veya yoğun bakımda çalıştığı belirlenmiştir. Hastalığın olası kaynağı değerlendirildiğinde \%51.4'ünde iş arkadaşı olduğu düşünülmüştür. Hastayla temas sırasında en sık kullanılan KKE cerrahi maske olarak belirlenmiştir (\%21.6). Hasta olan sağlık çalışanlarının 5 (\%13.5)'inin evinde birlikte yaşadığı kişilerde COVID-19 hastalığı varlığı saptanmıştır (Tablo VI). Kadın hasta çalışanların bu dönemde gebe olma- 


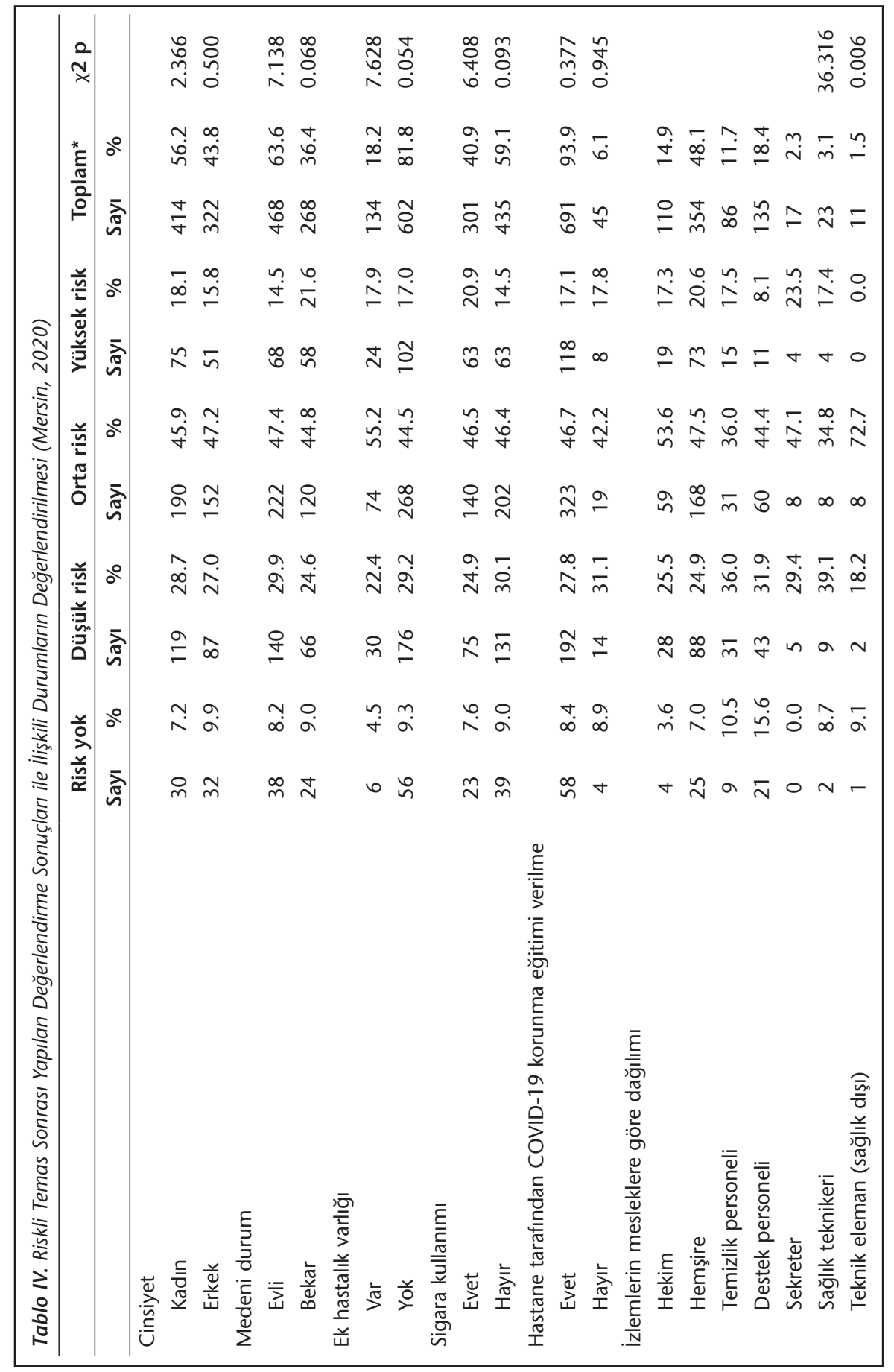




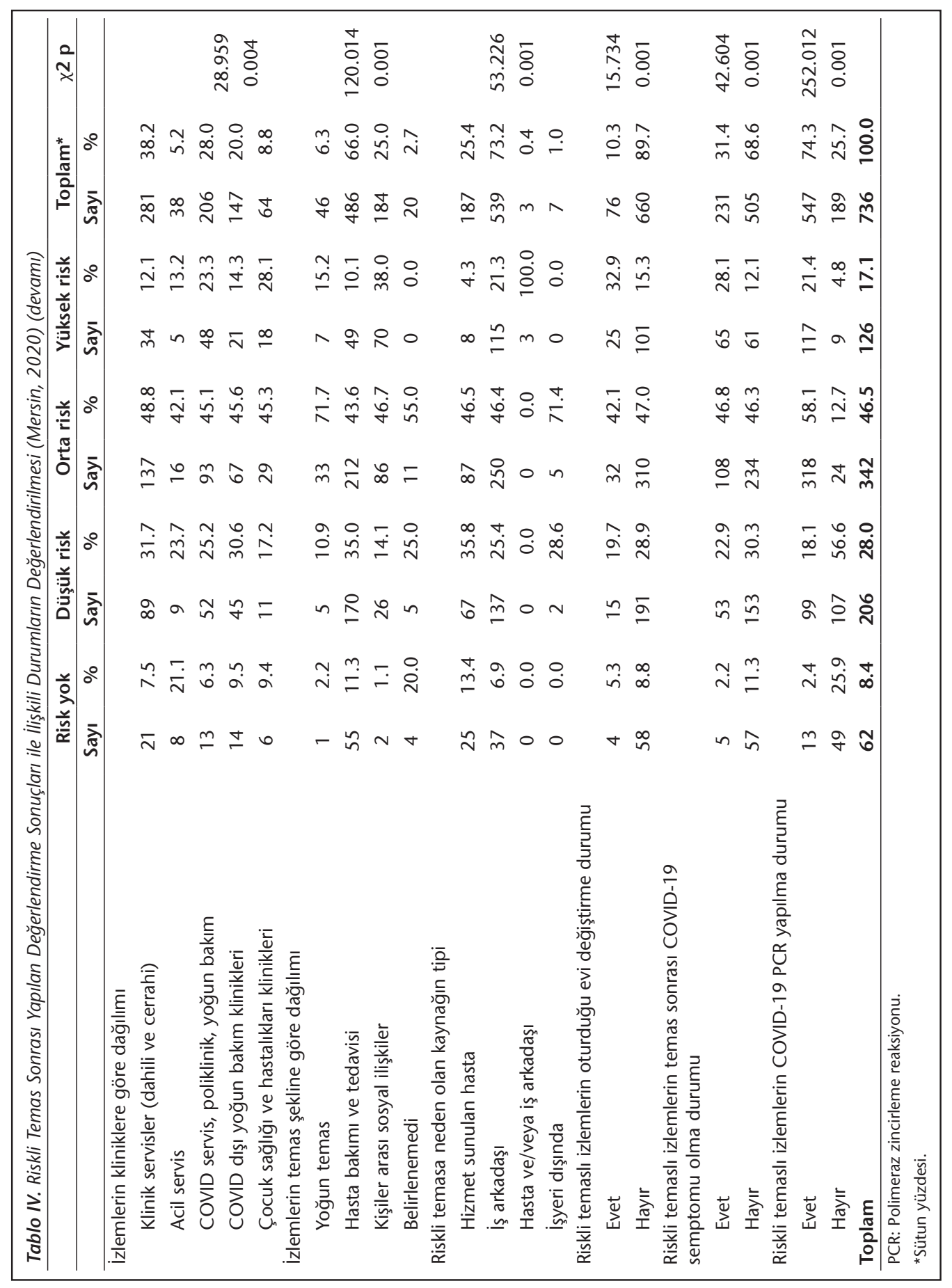




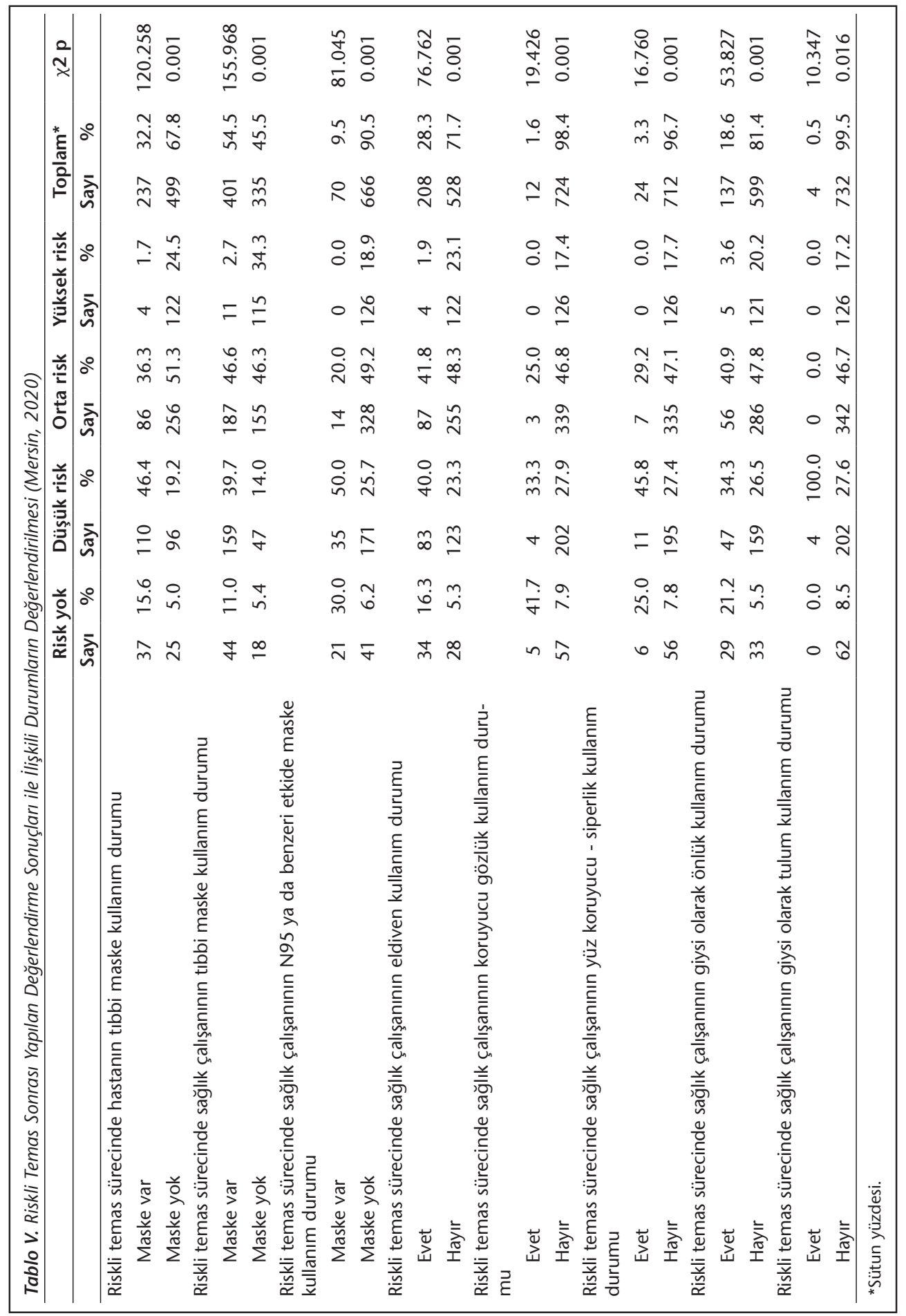


Tablo VI. COVID-19 Hasta Sağlık Çalışanlarının Demografik ve Çalışma Yaşamına ilişkin Özellikleri (Mersin, 2020)

\begin{tabular}{|c|c|c|}
\hline & Sayı & $\%$ \\
\hline \multicolumn{3}{|l|}{ Haftalara göre dağı̆ım } \\
\hline 1. hafta: 06-12 Nisan 2020 & 7 & 18.9 \\
\hline 2. hafta: 13-19 Nisan 2020 & 1 & 2.7 \\
\hline 3. hafta: 20-26 Nisan 2020 & 11 & 29.8 \\
\hline 4. hafta: 27 Nisan-03 Mayıs 2020 & 16 & 43.2 \\
\hline 5. hafta: 04-10 Mayıs 2020 & 2 & 5.4 \\
\hline \multicolumn{3}{|l|}{ Cinsiyet } \\
\hline Kadın & 24 & 64.8 \\
\hline Erkek & 13 & 35.2 \\
\hline \multicolumn{3}{|l|}{ Meslek } \\
\hline Hemşire & 18 & 48.6 \\
\hline Hekim & 7 & 18.9 \\
\hline Sekreter & 6 & 16.3 \\
\hline Destek personeli & 5 & 13.5 \\
\hline Temizlik personeli & 1 & 2.7 \\
\hline \multicolumn{3}{|l|}{ Görev yeri } \\
\hline COVID servis, poliklinik, yoğun bakım & 18 & 48.6 \\
\hline Klinik servisler (dahili ve cerrahi bütün klinikler) & 11 & 29.8 \\
\hline COVID dışı yoğun bakım klinikleri & 5 & 13.5 \\
\hline Çocuk sağlığı ve hastalıkları kliniği & 2 & 5.4 \\
\hline Acil servis & 1 & 2.7 \\
\hline \multicolumn{3}{|l|}{ Medeni durum } \\
\hline Evli & 24 & 64.9 \\
\hline Bekar & 13 & 35.1 \\
\hline \multicolumn{3}{|l|}{ Ek hastalık varlığı } \\
\hline Var & 9 & 24.3 \\
\hline Yok & 28 & 75.7 \\
\hline \multicolumn{3}{|l|}{ Sigara kullanımı } \\
\hline Evet & 16 & 43.2 \\
\hline Hayır & 21 & 56.8 \\
\hline \multicolumn{3}{|l|}{ Son 14 günde yurt dışına gidiş } \\
\hline Evet & 0 & 0.0 \\
\hline Hayır & 37 & 100.0 \\
\hline \multicolumn{3}{|l|}{ Son 14 günde il dışına gidiş } \\
\hline Evet & 3 & 8.2 \\
\hline Hayır & 34 & 91.8 \\
\hline \multicolumn{3}{|l|}{ Son 14 günde hastane dışında COVID-19 hasta ile temas } \\
\hline Evet & 2 & 5.4 \\
\hline Hayır & 35 & 94.6 \\
\hline
\end{tabular}


Tablo VI. COVID-19 Hasta Sağlık Çalışanlarının Demografik ve Çalısma Yaşamına ilişkin Özellikleri (Mersin, 2020) (devamı)

Son 14 günde eve misafir kabulü

Evet

Sayı $\quad \%$

Hayır

Hastane tarafından COVID-19 korunma eğitimi verilme

Evet

Hayır

Evinde COVID-19 hastası varlığı

Evet

Hayır

Hastalık tanısından sonra evini değiştirme durumu

Evet

Hayır

Hastalığın olası kaynağı

Hastalar

iş̧ arkadaşı

İşyeri dışında

Hasta ve/veya iş arkadaşı

Riskli temas sürecinde sağlık çalışanının tıbbi maske kullanımı

Evet

Hayır

Riskli temas sürecinde sağlık çalışanının N95 ya da benzeri etkide maske kullanımı

Evet

Hayır

Riskli temas sürecinde sağlık çalışanının eldiven kullanımı

Evet

Hayır

Riskli temas sürecinde sağlık çalışanının gözlük kullanımı

Evet

Hayır

Riskli temas sürecinde sağlık çalışanının yüz koruyucu kullanımı

Evet

Hayır

Riskli temas sürecinde sağılı çalışanının önlük kullanımı

Evet

Hayır

Riskli temas sürecinde sağlık çalışanının tulum kullanımı

Evet

Hayır 
dığı, ek hastalığı olan 9 çalışanın sadece ikisinde bu ek hastalığın COVID-19 riskli grupta yer aldığı belirlenmiştir.

COVID-19 hasta tanısı konulan 37 sağlık çalışanından beşinin hastalığı "Sağlık Çalışanı COVID-19 İzlem Birimi" tarafından riskli temaslı izlemi sürecinde saptanmıştır.

COVID-19 tanısı konan 37 kişiden 6 (\%16.2)'sının hastanede yatarak, 3 (\%8.1)'ünün evde ve 28 (\%75.7)'inin önce hastanede yatarak izlendiği, tedavinin geri kalanının evde tamamlandığı saptanmıştır. Hastanede yatarak tedavi uygulanan altı kişinin yatış süresinin ortalama $6.5 \pm 2.7$ (4-10) gün ve önce hastanede yatarak sonra evde tedavi gören 28 kişinin yatış süresinin ortalama $3.8 \pm 1.9$ (1-8) gün olduğu saptanmıştır. COVID-19 tanısı konan sağlık çalışanlarından yoğun bakımda yatan veya ölen olmamıştır.

Hasta olarak takip ve tedavileri yapılan 37 sağlık çalışanının tanı konulduğu tarihten itibaren işe dönüş sürelerinin ortalama $17.3 \pm 6.4$ (10-46) gün olduğu saptanmıştır.

\section{TARTIŞMA}

Mersin Üniversitesi Hastanesinde ilk COVID-19 hasta tanısı 22 Mart 2020'de, ilk COVID-19 sağlık çalışanı tanısı 10 Nisan 2020'de konulmuştur. DSÖ’nün durumu önemli bir sağlık problemi olarak bildirmesini takiben mart ayının başından itibaren hastane çalışanlarının konuyla ilgili bilgilendirme ve KKE kullanımı ile ilgi eğitim çalışmalar başlatılmıştır. İlk olgunun görüldüğü nisan ayına kadar sağlık çalışanların büyük bir kısmının katılımının sağlandığı eğitimler tamamlanmıştır. Çalışmayla eş zamanlı olarak da riskli temas olan bölümlerde riskin ortaya çıkmasını önleme ve sağlık çalışanlarında COVID-19 görülmesi durumunda eğitim çalışmaları tekrarlanmıştır.

Çalışmada beş haftalık süre içerisinde temasların yaklaşık yarısı orta riskli temas olarak değerlendirilmiştir. En fazla riskli temasın 20 Nisan-3 Mayıs 2020 tarihleri arasında olduğu görülmüştür ve bu dönemde yüksek riskli temas sayılarında da belirgin bir artış olmuştur. Yüksek riskli temasta artış, sağlık çalışanlarının hasta ile temasları sırasında yeterince KKE kullanmadıklarını göstermiştir. Yüksek riskli temas durumunda temas tarihinden itibaren yedi gün evde karantina uygulandığı için yüksek riskli temasın artmasıyla sağlık hizmeti veren personel sayısı azalmış ve diğer çalışanlar üzerindeki iş yükü artmıştır. Yüksek riskli olarak karantinaya alınan sağlık çalışanlarından beş kişinin izlemi sırasında yapılan PCR testlerinin pozitif olduğu saptanmıştır. Bu kişiler karantinada oldukları için iş yerinde riskli temaslıları olmamıştır. Bu durum hastanede sağlık çalışanlarına risk değerlendirmesi yapmanın önemli olduğunu göstermiştir.

Yüksek riskli temaslı olarak değerlendirilen sağlık çalışanlarının düşük riskli temaslılara göre daha genç yaşta oldukları görülmüştür. Bu durum, gençlerin meslekte geçirdikleri sürenin daha az olması ve daha tecrübesiz olmaları nedeniyle daha riskli davranışlar sergilediklerini düşündürmektedir. Ayrıca, genç olanlar COVID-19 temasının yüksek riskli olduğu birimlerde çalışıyor ve yüksek riskin olduğu işlemleri yapıyor olabilirler.

Çalışmada en fazla riskli teması olanlar ve COVID-19 hastalığına yakalanan hemşireler olmuştur. Hemşireler temel bakım hizmetlerini verirken hastalarla yakın temasları olmuş 
ve özellikle yatarak tedavi olan hastalarla daha uzun süre aynı ortamı paylaşmışlardır. Riskli temas sıklığı açısından ikinci sırada destek personelleri bulunmamıştır. Destek personeli hastaların taşınması, tetkikler için gerekli birimlere götürülmesi, hasta yatak çarşaflarının değiştirilmesi gibi görevler yapmaktadır. Hastalarla temasları fazla olmaktadır ancak temasları sırasında gerekli koruyucu önlemleri aldıkları için temaslarının risk oluşturmadığı görülmüştür. Sekreterler, poliklinik ve serviste hasta ve hasta yakınları ile ilk olarak karşılaşan meslek grubunu oluşturmaktadır. Hemşire ve sekreterlerin en fazla yüksek riskli teması olan meslek grupları oldukları görülmüştür. Hekimler tüm temaslılar içerisinde üçüncü sırada, hasta olan sağlık çalışanları arasında ise hemşirelerden sonra ikinci sırada yer almıştır. Hekimlerin temaslarının yarısından fazlasında orta risk grubunda yer aldıkları ve bu nedenle hasta muayenesi sırasında en azından cerrahi maske kullandıkları görülmüştür. Ancak, gerek hasta olarak gerekse riskli temaslı olarak izlenen sağlık personelinin KKE kullanımı sıklığının düşük olduğu izlenmiştir. ABD'de yapılan araştırmada çalışanların yarısı tüm hasta temasları sırasında KKE kullandığını bildirmiş, ancak pozitif test olanların \%9.3'ü KKE kullandığını bildirmiştir ${ }^{23}$. Sağlık personelinin yaptığı iş nedeniyle hasta ile teması sırasında mesafe kuralına uyması mümkün olamadığı için KKE kullanımının tam olması riski azaltmak için önemlidir. Zonguldak'ta bir üniversite hastanesinde yapılan çalışmada COVID-19 hastasıyla temasta uygunsuz KKE kullanımının hastalık riskini 11 kat artırdığı gösterilmiştir ${ }^{25}$. Amerika ve İngiltere'de yapılan bir çalışmada, COVID-19 hastasıyla doğrudan teması olan sağlık çalışanlarında KKE kullanımındaki eksikler ve KKElerin tekrar kullanımının COVID-19 hastalık riskini artırdığını, hatta KKE'lerin yeterli olarak kullanımında dahi hastalığa duyarlılığın arttığı bildirilmiştir ${ }^{30}$.

Riskli temas sırasında sağlık çalışanının en fazla dahili/cerrahi servislerde çalıştığı görülmüştür. Bu durum hastaların COVID-19 hastalığı dışındaki sağlık sorunları nedeniyle yatırılarak tedavi edilmeleri nedeniyle servislerde yeterli önlemin alınmadığını düşündürmüştür. Riskli temas ikinci sıklıkla COVID-19 hastalarına hizmet veren personelde görülmüştür. Bu hastaların şüpheli ve kesin COVID-19 hastası olduklarını bildikleri halde KKE'leri yeterince kullanmadıklarını düşündürmüştür. Riskli temasın en az olduğu birimler acil servis ve çocuk sağlığı ve hastalıkları klinikleridir. Hastanede kurulan triaj çadırlarında ateş, öksürük, nefes darlığı şikayeti olanlar doğrudan COVID-19 polikliniğine yönlendirilmiş ve oradan gerekli işlemleri gerçekleştirilmiştir. Bu nedenle acil serviste olası COVID-19 hastası başvurusu en aza indirilmiş ve bu birimde çalışanlar daha az riskli temasla karşılaşmıştır. Süreç içerisinde hastaneye hiç çocuk COVID-19 hasta yatışı olmadığı için riskli temas izleminin az olduğu diğer birim çocuk sağlığı ve hastalıkları kliniklerinin olduğu izlenmiştir. Personelin dönüşümlü olarak başka bölümlerde de çalışması ve diğer birimlerde hasta ile teması nedeniyle, bu birimde çalışan personel riskli temaslı olarak değerlendirilmiştir.

Sağlık personelinin sıklıkla hasta bakım ve tedavi hizmetlerini verirken riskli temaslarının olduğu belirlenmiştir. Bu durum, hemşire ve destek personelde daha fazla riskli temas görülmesi ile bağlantılı bir durum olarak değerlendirilebilir. Sağlık çalışanlarının işyerinde birlikte çalıştıkları kişilerle yemek yeme, çay-kahve içme, sigara içme gibi sosyal ilişkiler sırasındaki riskli temasları toplam temasların dörtte birini oluşturmuştur. Bu şekil- 
deki temaslarda maske takılmaması ve mesafe kurallarına uyulmaması nedeniyle yüksek riskli temas da fazla olmuştur. Sağlık çalışanlarının dinlenme sırasında temaslarının yüksek olma nedenlerinden bir tanesi de hastanedeki fiziki koşullardaki yetersizliktir. Kısa dinlenme molalarında çok sayıda personel küçük bir odada oturmak zorunda kalmıştır. Sağlık çalışanlarının iş arkadaşının hastalık açısından risk oluşturmayacağını düşünerek hastalara karşı aldıkları önlemleri iş arkadaşlarına karşı almadıkları gözlenmiştir. Oysa bu süreçte hastanede 37 sağlık çalışanında COVID-19 saptanmıştır. Zonguldak'ta bir üniversite hastanesinde yapılan çalışmada dinlenme odasında iş arkadaşı ile 15 dakikadan fazla maskesiz oturmanın hastalanma riskini yedi kat artırdığı belirtilmiştir ${ }^{25}$.

Bu çalışmada izlenen her 10 riskli temastan birisinin COVID-19 hastalarıyla temas etmeye başladığından beri yaşadıkları evi değiştirdikleri belirlenmiştir. Yaşadıkları yeri değiştirenlerin 3/4'ünün orta ve yüksek riskli teması olan sağlık çalışanları olmuştur. Hasta olarak tanı konan sağlık çalışanları arasında hastalık tanısı konulduktan sonra evini değiştirme oranı daha yüksek bulunmuştur. Görüşülen sağlık çalışanları ailelerini korumak için bu önlemi aldıklarını belirtmişlerdir. Hasta olan sağlık çalışanlarından beş kişinin, evinde birlikte yaşadığı kişilerde COVID-19 görülmüştür. Sağlık çalışanının hastalığı aldıktan sonra evde yaşadığı diğer kişilere mi bulaştırdığı yoksa sağlık çalışanının onlardan mı hastalığı aldıkları tam olarak ayırt edilemememiştir. Ancak, sağlık çalışanı hastalıkla karşılaşma açısından yüksek riskli olduğu için, hastalığı büyük olasılıkla onların eve taşıdıkları düşünülmüştür.

Çalışmada izlenen sağlık çalışanlarından \%6.7'si hasta olarak belirlenmiş ve bu kişilerin yaklaşık yarısını hemşireler ve $1 / 5^{\prime}$ i doktorlar oluşturmuştur. Zonguldak'ta bir üniversite hastanesinde COVID polikliniğine başvuran sağlık çalışanlarından \%7.1'inin PCR testi pozitif olarak belirlenmiştir. Hasta olan sağlık çalışanlarında ilk sırayı hemşireler almakta, onları temizlik personeli ve hekimler izlemektedir ${ }^{25}$. Almanya'da bu çalışmaya benzer şekilde en sık pozitiflik hemşirelerde, ikinci pozitiflik sıklığı hekimlerde belirlenmiştir ${ }^{20}$. ABD'de de en sık pozitiflik hemşirelerde görülmüştür ${ }^{23}$. Çalışmamızda hasta olarak tanı konulan sağlık personelinin yaklaşık yarısı COVID-19 poliklinik, servis veya yoğun bakımında çalışmaktaydı. COVID-19 hastalarıyla doğrudan temasın daha fazla olduğu bu birimlerde çalışan hemşire ve hekimlerin daha yoğun bir virüs yüküyle karşılaşmalarından kaynaklı, ayrıca KKE kullanımındaki eksiklikler nedeniyle hastalanma olasılıklarının arttığı düşünülmektedir.

Sonuç olarak, COVID-19 hastalığının Türkiye'de de yoğunlaşmaya başladığı nisan ayı boyunca Mersin Üniversitesi Hastanesinde görev yapan sağlık çalışanlarında riskli temaslar da artmıştır. Bir sağlık çalışanı, farklı hastalarla birden fazla kez riskli temas nedeniyle izlenmiştir. En fazla riskli temasın hemşire, destek personeli ve hekimlerde, en fazla COVID-19'un hemşire ve hekimlerde olduğu gözlenmiştir. Hastanede sadece COVID-19 hastalarının tanı ve tedavisinin gerçekleştiği birimlerde değil, hastanenin diğer servislerinde de riskli temaslar olmuştur. Hastaneye başvuran tüm hastaların ve yakınlarının tıbbi maske kullanımının sağlanması ve sağlık çalışanlarının KKE kullanımlarını eksiksiz gerçekleştirmeleri riski azaltacaktır. Ayrıca sağlık çalışanlarının COVID-19 hastalarına hizmet veren bölümlerde çalıştıktan sonra diğer bölümlerde çalışmaya geçmeden önce 
yedi gün karantinaya alınması ve sonrasında PCR sonucuna bakılarak tekrar çalışmaya başlaması hastane içerisinde bulaşı azaltabilir. Riskli temas sıklıkla hastaya verilen sağlık hizmeti sırasında ve kişiler arası sosyal ilişkiler sırasında olmuştur. İş arkadaşlarının hastalık bulaşmasında önemli bir risk faktörü olduğu görülmüştür. Sağlık çalışanlarının dinlenme alanlarında iş arkadaşlarıyla temasları sırasında maske kullanmamaları ve aralarına yeterli mesafe koymamaları riskli temasta önem arz etmiştir. Hastanelerde sağlık çalışanlarının dinlenme alanlarının fiziki olarak iyileştirilesi ve dinlenme molalarının dönüşümlü olarak gerçekleştirilerek aynı anda en az sayıda kişinin odada olması bulaş riskini azaltacaktır. Sağlık çalışanları için hastanede kurulan COVID-19 izlem birimi tarafından yapılan risk değerlendirmesine göre belirlenen sorunların çözümünde hastane yönetimi, birimin önerilerini dikkate almış ve bu sayede temaslı sayılarında ve hastalanan sağlık çalışanlarının sayılarında azalma gözlenmiştir. Bu süreçte verilen eğitimler ve sağılı çalışanlarının olaya daha ciddiyetle bakışının da bu azalmada rol oynadığı düşünülmektedir.

\section{ETIK KURUL ONAYI}

Bu çalışma, T.C. Sağlık Bakanlığının (Tarih: 14.06.2020 ve Sayı: 2020-06-10T14_34_14) ve Mersin Üniversitesi Klinik Araştırmalar Etik Kurulunun onayı ile gerçekleştirildi (Tarih: 08.07.2020 ve Karar No: 2020/475).

\section{ÇIKAR ÇATIŞMASI}

Bu çalışma ile ilgili olarak çıkar çatışması bildirilmemiştir.

\section{KAYNAKLAR}

1. World Health Organization (WHO). Novel Coronavirus (2019 CoV) Situation Report-1. 21 January 2020. Available from: https:/www.who.int/docs/default-source/coronaviruse/situation-reports/20200121-sitrep1-2019-ncov.pdf?sfvrsn=20a99c10_4

2. World Health Organization (WHO). Novel Coronavirus (2019 CoV) Situation Report-10. 30 January 2020. Available from: https://www.who.int/docs/default-source/coronaviruse/situation-reports/20200130-sitrep10-ncov.pdf?sfvrsn=d0b2e480_2 (Accessed date: 27 August 2020)

3. World Health Organization (WHO). Coronavirus disease 2019 (COVID-19) Situation Report-51. 11 March 2020. Available from: https://www.who.int/docs/default-source/coronaviruse/situation-reports/20200311sitrep-51-covid-19.pdf?sfvrsn=1ba62e57_10 (Accessed date: 27 August 2020)

4. Anadolu Ajansı (AA). Milliyet Gazetesi. Son dakika... Corona virüsü Türkiye'de! Açılama 00.53'te geldi. Available from: https://www.milliyet.com.tr/galeri/son-dakika-corona-virusu-turkiyede-aciklama-00-53tegeldi-6163129/8 (Accessed date: 15 July 2020)

5. World Health Organization (WHO). Coronavirus Disease (COVID-19) Dashboard. Available from: https:// covid19.who.int/ (Accessed date: 10 November 2020)

6. T.C. Sağlık Bakanlığı. COVID-19 Bilgilendirme Sayfası. Available from: https://covid19.saglik.gov.tr/ (Accessed date: 10 November 2020)

7. Harapana H, Itohd N, Yufikae A, Winardif W, Keamg S, Teh H, et al. Coronavirus disease 2019 (COVID-19): A literature review. J Infect Public Health 2020; 13(5): 667-73.

8. Zhai P, Ding Y, Wu X, Long J , Zhong Y, Li Y. The epidemiology, diagnosis and treatment of COVID-19. Int J Antimicrob Agents 2020; 55 (5): 105955.

9. Singhal TA. Review of coronavirus disease-2019 (COVID-19). Indian J Pediatr 2020; 87(4): 281-6. 
10. World Health Organization (WHO). Transmission of SARS-CoV-2: implications for infection prevention precautions. Scientific brief. 9 July 2020 Available from: file://C:/Users/ASUS/Downloads/WHO-2019-nCoVSci_Brief-Transmission_modes-2020.3-eng.pdf (Accessed date: 15 July 2020)

11. Secon H. Nearly 3,400 Chinese healthcare workers have gotten the coronavirus and 13 have died. 2020. Available from: https://www.busin essin sider.com/healt hcare -worke rs-getti ng-coron aviru s-500-infec ted-2020-2 Published 4 March 2020. (Accessed date: 28.07.2020) (Accessed date: 28 July 2020)

12. Steensels D, Oris E, Coninx L, Nuyens D, Delforge ML, Vermeersch $P$, et al. Hospital-Wide SARS-CoV-2 antibody screening in 3056 staff in a tertiary center in Belgium. JAMA 2020; 324(2): 195-7.

13. Rivett L, Sridhar S, Sparkes D, Routledge M, Jones NK, Forrest S, et al. Screening of healthcare workers for SARS-CoV-2 highlights the role of asymptomatic carriage in COVID-19 transmission. eLife 2020; 9: e58728.

14. Jones NK, Rivett L, Sparkes D, Forrest S, Sridhar S, Young J, et al. Effective control of SARS-CoV 2 transmission between healthcare workers during a period of diminished community prevalence of COVID-19. eLife 2020; 9: e59391.

15. Lazzerini M, Putoto G. COVID-19 in Italy: momentous decisions and many uncertainties. Lancet 2020; 8: e641-e642.

16. Shields AM, Faustini S., Perez-Toledo M, Jossi S, Aldera E, Allen JD., et al. SARS-CoV-2 seroconversion in healthcare workers. medRxiv preprint 2020.

17. Hunter E, Price DA, Murphy E, van der Loeff IS, Baker KF, Lendrem D, et al. First experience of COVID-19 screening of health-care workers in England. Lancet 2020; 395(10234): e77-e78.

18. Reguly E. Italian doctors' fatalities reach tragic levels as they fight COVID-19 in overburdened hospitals. The Globe and Mail Available from: https://www.theglobeandmail.com/world/article-italian-doctors-fatalitiesreach-tragic-levels-as-they-fight-covid-1/ (Accessed date: 15 July 2020)

19. Guan W, Ni Z, Hu Y, Liang W, Ou C, He J, et al. Clinical characteristics of coronavirus disease 2019 in China. N Engl J Med 2020; 382: 1708-20.

20. Nienhaus A, Hod R. COVID-19 among health workers in Germany and Malaysia. Int J Environ Res Public Health 2020; 17(13): 4881.

21. Wu Z, McGoogan JM. Characteristics of and important lessons from the coronavirus disease 2019 (COVID-19) outbreak in China: summary of a report of 72314 cases from the Chinese Center for Disease Control and Prevention. JAMA 2020; 323(13): 1239-42.

22. Kluytmans M, Buiting A, Pas S, Bentvelsen R, van den Bijllaardt W, van Oudheusden A, et al. SARS-CoV-2 infection in 86 healthcare workers in two Dutch hospitals in March 2020. medRxiv 2020.

23. Barrett ES., Horton DB., Roy J, Gennaro ML, Brooks A, Tischfield J, et al. Prevalence of SARS-CoV-2 infection in previously undiagnosed health care workers at the onset of the U.S. COVID-19 epidemic. medRxiv 2020.

24. World Health Organization (WHO). Keep health workers safe to keep patients safe. 17 September 2020. News release Geneva. Available from: https://www.who.int/news-room/detail/17-09-2020-keep-healthworkers-safe-to-keep-patients-safe-who

25. Çelebi G, Pişkin N, Çelik Bekleviç A, Altunay Y, Salcı Keleş A, Tüz MA, et al. Specific risk factors for SARS-CoV-2 transmission among health care workers in a university hospital. AJIC 2020; 48(10): 1225-30.

26. Sağlık Bakanı Koca: Salgın artarak devam ediyor. Available from: https://www.ntv.com.tr/turkiye/son-dakikahaberi-saglik-bakani-kocakonusuyor,ilKTUHPgp0yNH8KOauEgaQ (Accesed date: 10.09.2020)

27. Uluslararası Af Örgütü. Küresel: Tüm dünyada 7 binin üzerinde sağlık çalışanı COVID-19 nedeniyle öldü. 03 Eylül 2020. Available from: https://www.amnesty.org.tr/icerik/kuresel-tum-dunyada-7-binin-uzerindesaglik-calisani-covid-19-nedeniyle-oldu (Accessed date: 10 September 2020)

28. Türk Tabipleri Birliği COVID-19 İzleme Kurulu. COVID-19 Pandemisi Altıncı Ay Değerlendirme Raporu. Sağlık Çalışanlarının Sağlığı. COVID-19 Hastalığına Yakalanmış Sağlık Çalışanları. 17 Eylül 2020, S:304

29. T.C. Sağlık Bakanlığı Halk Sağlığı Genel Müdürlüğü. COVID-19 (SARS-CoV-2 Enfeksiyonu) Temaslı Takibi, Salgın Yönetimi, Evde Hasta İzlemi ve Filyasyon. Bilimsel Danışma Kurulu Çalışması. Ankara, 14 Eylül 2020, S:17.

30. Nguyen LH, Drew DA, Graham MS, Joshi AD, Guo CG, Ma W, et al. Risk of COVID-19 among front-line healthcare workers and the general community: a prospective cohort study. Lancet Public Health 2020; 5: e475-e83. 